
(Case Study: Humingbad Clothing)

\title{
Usulan Strategi Optimalisasi Akun Media Sosial Dalam Upaya Meningkatkan Reach Melalui Instagram Advertising (Studi Kasus: Humingbad Clothing)
}

\author{
Fahri Setia ${ }^{1}$, Cecep Safa' atul Barkah ${ }^{2}$, Tetty Herawaty ${ }^{3}$, Lina Auliana $^{4}$ \\ ${ }^{1234}$ Universitas Padjadjaran \\ fahri19001@mail.unpad.ac.id ${ }^{1}$, cecep.barkah@unpad.ac.id ${ }^{2}$
}

\begin{tabular}{|c|c|}
\hline Article info & Abstract \\
\hline Article history: & The success of a company is not only seen from profits, but many other \\
\hline Received $05^{\text {th }}$ July 2021 & factors that influence it. This research is motivated by the level of reach \\
\hline Received in revised form $12^{\text {th }}$ November & that the company gets through social media, which can be seen by the \\
\hline 2021 & company's way of digital promotion. This study aims to determine how \\
\hline Accepted $15^{\text {th }}$ November 2021 & $\begin{array}{l}\text { to determine the right strategy in increasing the reach or reach on the } \\
\text { Hummingbad Clothing Instagram account with descriptive qualitative } \\
\text { methods, data collection is done by interview and also observation. }\end{array}$ \\
\hline Keywords: & $\begin{array}{l}\text { The data obtained were processed using a number of methods of } \\
\text { analysis of Sustainable Competitive Advantage (SCA), VRIO model }\end{array}$ \\
\hline $\begin{array}{l}\text { Advertising, Marketing, Reach, } \\
\text { Social Media. }\end{array}$ & $\begin{array}{l}\text { analysis and TOWS analysis. Then the researcher analyzed } \\
\text { Hummingbad Clothing's Instagram account with the Reach marketing } \\
\text { matrix to propose a strategy to increase reach through advertising. The } \\
\text { recommended suggestion is the use of Instagram Ads. }\end{array}$ \\
\hline
\end{tabular}

@ 2022 ASMTB PRESS

\section{PENDAHULUAN}

Era modern sekarang ini perkembangan internet berlangsung sangat pesat. Banyak faktor yang mempengaruhi perkembangan internet diseluruh dunia. Termasuk di Indonesia sendiri. Internet sudah seakan menjadi kebutuhan primer masyarakat, setiap hari masyarakat membutuhkan akses internet untuk keperluan bersosialisasi, browsing, serta melaksanakan kegiatan pekerjaan sehari-hari. Internet sendiri ialah kumpulan dari berbagai komputer yang terkoneksi atau saling berhubungan diseluruh dunia denga kabel atau serat optic sebagai medianya (Hartono, Jogiyanto 2009:1).

Pemanfaatan internet sangat berpengaruh dalam segala bidang dan sektor, salah satu contohnya adalah disektor wirausaha. Internet dipakai menjadi sebuah alat pertukaran informasi menggunakan teknologi atau secara elektronik kemudian seiring berkembangnya ilmu pengetahuan internet menjadi sebuah alat atau aplikasi strategi bisnis diantaranya adalah untuk periklanan produk untuk menarik perhatian konsumen dan meningkatkan value produk itu sendiri. Menurut Kotler (2005:277) iklan merupakan bentuk pemaparan atau presentasi secara umum dan juga promosi sebuah barang atau jasa yang dihasilkan produsen yang harus 
dibayar oleh sponsor. Sebuah perusahaan akan melakukan pemasaran produk yang diantaranya dengan menggunakan iklan untuk menjangkau konsumen yang lebih luas serta mengenalkan manfaat dan fungsi produknya kepada konsumen. Penyusunan konsep serta konten yang dibungkus secara menarik akan mudah diingat oleh konsumen sehingga pemasaran semakin efektif dan sesuai dengan target pasar.

Periklanan sendiri adalah sebuah strategi dalam pemasaran produk perusahaan dengan tujuan nilai jual dan branding perusahaan meningkat. (Kotler dan Lane 2007) menjelaskan bahwa pemasaran merupakan sebuah proses dimana dalam satu kelompok masyarakat atau individu terjadi pertukaran, pembuatan ataupun meciptakan produk bernilai guna memenuhi kebutuhan dan keinginannya. Perkembangan jaman yang sudah mengenal internet dimanfaatkan dengan sarana promosi perusahaan, seperti penggunaan media sosial. Menurut Kaplan dan Haelein (2014:26) media sosial adalah sebuah aplikasi teknologi berbasis internet yang memungkinkan pertukaran informasi dan penciptaan user-generated content. Media sosial sendiri sudah banyak digunakan oleh masyarakat sebagai sarana komunikasi sosial dunia maya. Berbagai platform media sosial sangat banyak yang bisa dimanfaatkan diantaranya adalah Instagram.

Pengertian pemasaran yang dikutip dari Kotler dan Lane (2007) merupakan proses sosial dalam sebuah kelompok masyarakat yang melakukan pertukaran, penawaran dan penciptaan sebuah produk yang memiliki nilai untuk memenuhi kebutuhan dan keinginan masyarakat atau kelompok tersebut. Konsep pemasaran berkembang secara pesat, salah satunya adalah Digital Marketing. Peran Digital Marketing adalah sebuah kegiatan pemasaran melalui beberapa media berbasis internet web, meliputi adsversiting, email dan blog. Menggunakan media sosial selain untuk browsing bisa dikatakan termasuk kedalam media digital marketing (Ridwan Sanjaya dan Josua Tarigan 2004).

Kegiatan pemasaran melalui iklan dilakukan disalah satu perusahaan dibidang konveksi yaitu Humingbad Clothing yang berlokasi di Ciamis, Jawa Barat. Humingbad Clothing adalah salah satu UMKM yang bergerak dibidang konveksi yaitu usaha produksi pakaian dan aksesoris yang dibuat secara massal. Lebih detailnya adalah industri untuk pembuatan pakaian jadi seperti kaos, kemeja, jaket, jersey, gantungan, topi, tas dan lain sebagainya. Humingbad adalah usaha konveksi yang sedang berkembang dibidangnya tersebut, hal ini jelas membuktikan bahwasanya Humingbad masih mencari target pasar yang cocok seperti komunitas, sekolah ataupun organisasi-organisasi yang memerlukan pakaian sebagai identitas kelompok mereka. Penggunaan Instagram oleh Humingbad merupakan salah satu langkah untuk menjangkau para pengguna media sosial lain untuk melihat profil, katalog produk serta konten yang dibuat oleh perusahaan Humingbad. Dalam penggunaan media sosial, profile akun menjadi kunci untuk melihat seberapa besar akun tersebut memiliki pengaruh dan seberapa banyak akun tersebut dijangkau oleh sesama pengguna. Instagram sendiri dalam profil akun terdapat nama akun, postingan, jumlah pengikut, jumlah yang diikuti dan bisa melihat statistik akun yang dijangkau, impresi serta statistik lainnya. Setiap postingan yang diupload memiliki statistik yang dapat dilihat seperti jumlah like, komentar, dan jumlah orang yang berbagi postingan tersebut. Berikut data akun Instagram Humingbad:

Tabel 1. Data Akun Instagram Humingbad Clothing

\begin{tabular}{|c|c|}
\hline Nama Akun & @ humingbad.customize \\
\hline Jumlah Postingan & 103 \\
\hline Jumlah Pengikut & 947 \\
\hline Jumlah Diikuti & 144 \\
\hline
\end{tabular}

Sumber: Data Statistik Akun Instagram Humingbad Clothing

Pengelolaan media sosial menjadi kunci dalam sarana promosi atau iklan perusahaan untuk menjangkau konsumen yang lebih luas. Humingbad sendiri harus mengetahui apakah media sosialnya sudah menjangkau konsumen yang lebih luas sesuai dengan target perusahaan itu sendiri. Untuk mengukur hal 
tersebut, Humingbad dapat menggunakan matriks pemasaran yaitu Reach yang merupakan salah satu matriks dari matriks pemasaran yang digunakan dalam penetapan strategi pemasaran.

Fitur Reach sendiri di Instagram sudah diatur pada setiap akun Instagram mode bisnis dengan menu Insight Profile untuk melihat jumlah kunjungan profile yang bisa dilihat dalam 30 hari terakhir. Data tersebut tidak hanya berisisi jangkauan akun, tetapi terdapat beberapa data seperti impresi, lokasi pengunjung, usia pengunjung, jenis kelamin serta data lainnya. Jika jangkauan akun tersebut tinggi bisa berdampak dengan peningkatan promosi dari akun media sosial perusahaan tersebut sehingga menguntungkan perusahaan dalam penjualan produk. Berikut jumlah Reach atau akun yang dijangkau dan Impresi yang didapat oleh Humingbad Clothing sebagai berikut:

\section{Gambar 1 dan 2 Data Statistik Akun Instagram Humingbad Clothing}
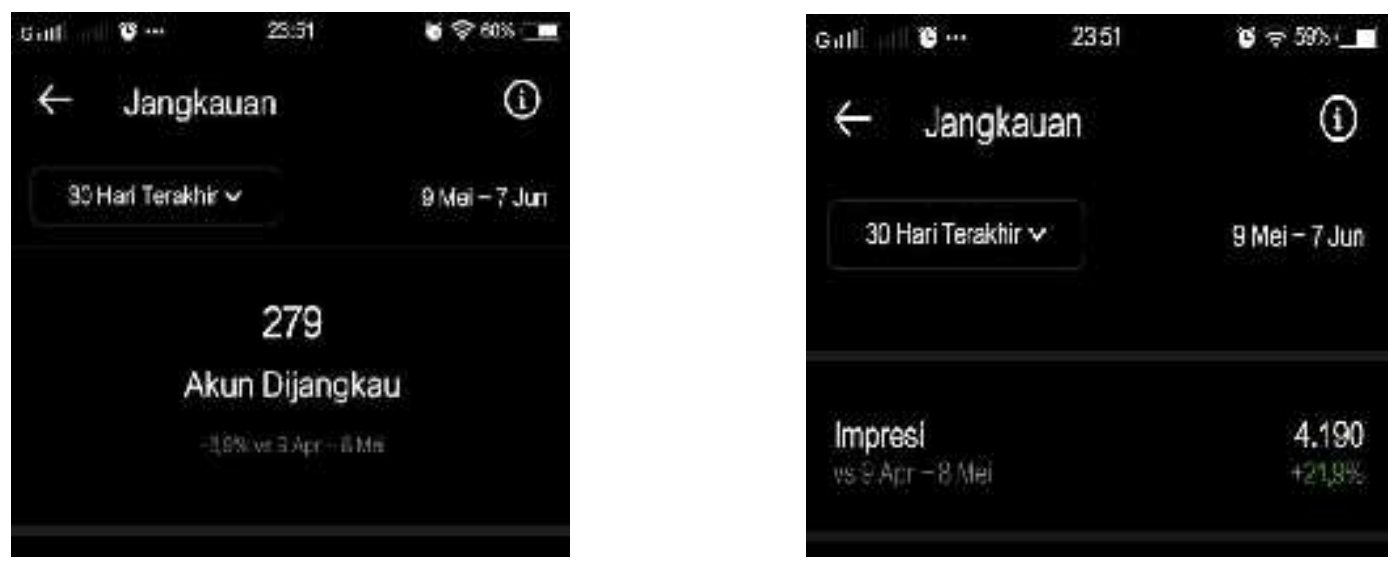

Jangkauan yang didapat oleh Humingbad sendiri masih berada dibawah dari jumlah pengikut yang mengikuti akun Instagram, yang artinya dilihat dari fenomena diatas penulis menganalisa bagaimana pengelolaan media sosial khususnya instagram sehingga bisa meningkatkan Reach dari akun instagram Humingbad itu sendiri.

\section{KAJIAN PUSTAKA}

\section{Iklan}

Iklan adalah sebuah cara komunikasi terhadap konsumen yang bertujuan untuk mempromosikan produk perusahaan atau jasa sehingga calon konsumen bisa mempengaruhi minat beli calon konsumen sesuai keinginan dari si pembuat iklan (William Pattis, 1993). Menurut (Kotler \& Amstrong, 2004:Lamb et al, 2001) Perikalan adalah komunikasi yang didalamnya terdapat strategi promosi yang arah komunikasinya adalah satu arah, didalamnya terdapat informasi mengenai produk perusahaan yang dibayar oleh seorang pemasar. Untuk meningkatkan penjualan, diperlukan sebuah perencanaan yang matang serta indikator dalam melakukan periklanan. Menurut Kotler yang dialihbahasakan oleh Hendra Teguh (2008) ada beberapa hal yang perlu dipertimbangkan yaitu:
a. Misi (Mission)
Menyangkut target penjualan beserta tujuan dari periklanan itu sendiri.
b. Anggaran (Money)
Anggaran biaya yang dikeluarkan perusahaan.
c. Media (Media)
Pemilihan mengenai media periklanan yang akan dipilih.
d. Pesan (Message)
Berisi mengenai konsep serta evaluasi mengenai iklan, dan mengkaji ulang isi atau makna yang tersampaikan kepada konsumen. 


\section{e. Pengukuran (Measurement)}

Untuk melihat dampak dari iklan yang telah ditayangkan kepada publik serta dampak penjualan produk perusahaan.

\section{Digital Marketing}

Digital Marketing adalah sebuah kegiatan pemasaran melalui beberapa media berbasis internet web, meliputi adsversiting, email dan blog. Menggunakan media sosial selain untuk browsing bisa dikatakan termasuk kedalam media digital marketing (Ridwan Sanjaya dan Josua Tarigan 2004). Perkembangan dari Digital Marketing sendiri yang menggunakan media internet melalui web dan jejaring sosial menawarkan akses baru dalam periklanan. Digital Marketing bisa membantu perusahaan dalam mempromosikan serta memasarkan produk kepada konsumen yang lebih luas, sehingga membuka pangsa pasar yang baru. Digital Marketing sendiri bisa memecahkan solusi promosi yang memiliki keterbatasan waktu, komunikasi dan jarak.

\section{Resources Based View (RBV)}

Teori RBV adalah teori terapan untuk menerapkan dan mengembangkan model- model sumber daya sebuah perusahaan terhadap fungsi organisasi itu sendiri yang diambil dari strategi manajemen SDM (Strategic Human Resources Management). Menurut Brahmana (2007), sumber daya internal perusahaan sangat krusial untuk pengembangan perusahaan dengan para pesaing, dibandingkan faktor eksternal perusahaan. Menurut Fred R. David, (2009) sumber daya internal perusahaan dapat dikategorikan menjadi 3 kategori yaitu:

1. Sumber daya fisik, meliputi semua pabrik, bangunan, peralatan operasional, lokasi, bahan baku, mesin, sistem dan teknologi.

2. Sumber daya manusia, meliputi karyawan, kemampuan, dan pengalaman.

3. Sumber daya organisasi, meliputi struktur perusahaan, proses perencanaan dan strategi perusahaan.

\section{Analisis VRIO Model}

VRIO model merupakan teknik analisis untuk mengukur sumber daya dan kemampuan dari perusahaan untuk dapat menjadi sumber keunggulan kompetitif yang berkelanjutan (Sustainable Competitive Advantage) melalui analisis sumber daya internal dan kemampuan perusahaan. Analisis VRIO mencakup pertanyaan mengenai Value (nilai), Rarity (langka), Imitability (kemungkinan peniruan), Organization (organisasi).

1. Value

Sumber daya dan kemampuan perusahaan yang bisa dimanfaatkan untuk meraih peluang serta menghindari ancaman baru.

2. Rarity

Sumber daya yang memiliki keuinikan kemampuannya dan dapat diklasifikasikan sebagai sesuatu yang jarang.

3. Imitability

Sumber daya dan kapabilitas yang perlu untuk tidak dapat ditiru bahkan tergantikan.

4. Organization

Perusahaan dapat mengelola dan mengatur sistem manajerial, proses, kebijakan, budaya dan struktur organisasinya.

\section{Analisis TOWS}

Analisis TOWS adalah analisis untuk mendapatkan strategi efeketif terhadap pasar ataupun kondisi publik saat itu dengan memanfaatkan peluang dan ancaman dipakai untuk mengetahui kondisi lingkungan eksternal. Kekuatan dan ancaman dipakai untuk menganalisis lingkungan internal perusahaan. (Galvan, 2004). TOWS terdiri dari threats, opportunity, weakness, strenght. Hal ini berutujuan untuk kemajuan dan kesuksesan sebuah perusahaan. 


\section{Reach}

Reach adalah jumlah orang atau persen populasi yang terpapar suatu iklan, dalam buku Third Edition yang disusun oleh Neil T. Bendle, Paul W. Farris, Phillip E. Preifer dan David J. Reibstein, Reach bertujuan untuk mengukur iklan yang tersebar dipopulasi. Reach adalah jangakuan untuk membentuk sebuah brand termasuk merek, produk serta layanan yang ditawarkan perusahaan kepada konsumen melalui media sosial guna untuk mengukur traffic pengunjung pada media sosial perusahaan (Chaffey, 2011).

Matriks Reach bertujuan untuk mengukur seberapa luas jangkauan sebuah web, ketika perhitungan data sudah ditemukan akan didapat hasil konversi yang bisa dilihat seberapa sesuai jangkauan akun yang telah ditargetkan perusahaan dan diukur tingkat efektif sistem pemasaran yang dilakukan khususnya sebagai sarana promosi perusahaan.

Matriks Reach menjadi matriks yang cocok untuk digunakan apabila perusahaan ingin mengetahui sejauh mana jangkauan iklan yang dilakukan perusahaan khususnya dalam media sosial Instagram sehingga didapat data yang dihasilkan untuk mengukur tingkat jangkauan dalam promosi digital khususnya promosi akun sosial media Humingbad Clothing. Semakin tinggi jangkauan yang didapat, jumlah pengikut akun perusahaan semakin meningkat hal ini bisa berdampak kepada tingkat penjualan produk perusahaan tersebut.

Perhitungan matriks Reach dapat dihitung dengan membagi impresi dengan rata-rata frekuensi. Dengan melakukan pengukuran tersebut, Humingbad dapat mengetahui berapa hasil Reach yang didapatkan.

\section{METODE PENELITIAN}

Penelitian ini menggunakan pendekatan kualitatif dengan metode deskriptif. Menurut Sugiyono (2007:1), penelitian kualitatif adalah penelitian yang digunakan untuk meneliti sebuah objek alamiah yang dimana peneliti berposisi sebagai pemegang kunci, teknik pengumpulan data dilakukan secara gabungan dengan analisis data bersifat induktif serta hasil dari penelitian tersebut lebih ditekan maknanya daripada generalisasi.

Data yang dikumpulkan diperoleh dari data internal Humingbad dengan wawancara dengan pemilik bisnis serta penelitian dilakukan terhadap data akun media sosial Instagram perusahaan Humingbad dengan melihat Insight selama 30 hari terakhir pada bulan Mei-Juni 2021. Pendekatan studi kasus menggunakan matriks pemasaran Reach untuk mengukur dan menyelidiki strategi dan kinerja pemasaran yang dilakukan perusahaan Humingbad. Penelitian ini didukung dengan kerangka analisis Internal Based Resource meliputi tangible dan intangible, VRIO serta analisis SCA (Sustainable Competitive Advantage) dan juga analisis TOWS dengan tipe penelitian deskriptif yang bertujuan untuk penjelasan secara tepat terkait strategi yang dilakukan Humingbad untuk menjangkau pengguna media sosial yang lebih luas.

\section{HASIL DAN PEMBAHASAN}

Hasil analisis mengenai Internal Based Resource atau RBV terhadap perusahaan Humingbad yang dimana hal ini menjadi kekuatan internal yang penting bagi perusahaan, dikarenakan bisa menjadi indikator perbandingan dengan para pesaing dibidang konveksi sendiri. Internal Based Resource Humingbad terbagi menjadi dua yakni Tangible dan Intangible yaitu:

Tabel 2. Data Internal Based Resources Humingbad Clothing

\begin{tabular}{|c|c|}
\hline Tangible & Intangible \\
\hline Tanah & Relasi \\
\hline Bangunan & Ekuitas Merek \\
\hline Peralatan dan Perlengkapan & Pelayanan \\
\hline Sumber Daya Manusia & Inovasi \\
\hline
\end{tabular}




\begin{tabular}{|c|c|}
\hline Bahan Baku & \\
\hline Modal & \\
\hline Media Sosial & \\
\hline
\end{tabular}

Sumber: Penulis, 2021

Berikut data pesaing Humingbad khususnya di daerah Ciamis yaitu:

Tabel 3. Data Internal Based Resource Pesaing Humingbad

\begin{tabular}{|l|l|l|l|}
\hline \multicolumn{2}{|c|}{ BARAYA HOOD } & \multicolumn{2}{c|}{ ANIMO } \\
\hline Tangible & Intangible & Tangible & Intangible \\
\hline Peralatan operasional & Pelanggan Tetap & SDM & Ekuitas Merek \\
\hline SDM & Pelayanan & Bahan Baku & Pangsa Pasar Luas \\
\hline Bahan Baku & Produk Inovatif & Peralatan & Produk Inovatif \\
& & Operasional & \\
\hline
\end{tabular}

Sumber: Penulis, 2021

Data diatas menunjukan beberapa keunggulan dari internal perusahaan pesaing dibidang konveksi di daerah Ciamis. Sementara data internal perusahaan Humingbad yang didapat meliputi tangible dan intangible yang dimiliki perusahaan Humingbad dengan rincian sebagai berikut:

\section{A. Tangible}

1. Tanah

Tanah yang dimiliki Humingbad adalah milik sendiri yang dimana tanah menjadi tempat operasional usaha dan juga tempat berdirinya bangunan untuk menunjang operasional perusahaan.

2. Bangunan

Humingbad memiliki bangunan yang kokoh dan terawat sebagai penyimpanan peralatan serta produk yang sudah jadi. Sarana ini juga sebagai pelindung segala bentuk inventaris dari Hummingbad.

3. Peralatan dan Perlengkapan

Humingbad memiliki variasi dan jumlah alat produksi yang bermacam-macam diantaranya mesin jahit, obras, overdeck, mesin potong, mesin press, mesin cutting, meja sablon rel 20 palet, curring, alat sablon manual, laptop, mesin print, dan fasilitas penunjang lainnya sehinga dapat memenuhi penawaran yang ada.

4. Sumber Daya Manusia

Humingbad memiliki 3 karyawan untuk melaksanakan proses produksi dan menjalakan kegiatan perusahaan lainnya.

5. Bahan Baku

Humingbad memiliki berbagai varian jenis bahan baku sesuai produk yang dipesan, seperti stok kain dan sablon yang mampu dijaga rantai pasok bahan baku secara berkelanjutan.

6. Modal

Humingbad memiliki modal kas sebesar 50 juta sebagai anggaran perusahaan untuk menunjang keperluan perusahaan.

7. Media Sosial 
Humingbad memiliki akun Instagram yang berisi mengenai profile perusahaan, kontak yang dapat dihubungi, konten feeds Instagram yang menarik dan juga katalog produk yang dimiliki.

\section{B. Intangible}

1. Relasi

Humingbad memiliki relasi yang baik dengan para supplier dan juga pelanggan dan bisa membangun kekuatan tawar menawar dengan supplier.

2. Ekuitas Merek

Humingbad Clothing dapat menjaga citra baik merek mereka dimata konsumen serta mampu menciptakan loyalitas pelanggan dimana loyalitas pelanggan bisa meningkatkan pembelian dengan jangka panjang (Tjiptono, 2004:110).

3. Pelayanan

Pelayanan yang ramah dan cekatan baik di sosial media maupun secara langsung (offline).

4. Inovasi

Humingbad Clothing mampu menghasilkan inovasi dari desain sablon yang bisa juga sesuai keinginan konsumen atau custom.

Data Internal Based Resource tersebut ditujukan untuk melihat beberapa indikator yang dimiliki Humingbad Clothing untuk membandingkan dengan para pesaingnya seperti Baraya Hood dan Animo khususnya dibidang konveksi di Ciamis. Berdasarkan data tersebut Humingbad memiliki keunggulan dalam Media sosialnya, pengelolaan konten yang informatif menjadi keunggulan dibanding para pesaingnya. Data tersebut bisa menunjang untuk pengembangan perusahaan dan bisa menjadi acuan untuk memperbaiki sisi perusahaan yang cukup kurang.

Setelah mendapatkan data Internal Based Resource tersebut didapatkan data dari analisis VRIO model untuk mendapatkan data Sustainable Competitive Advantage atau bisa disebut SCA sebagai keunggulan dari Hummingbad Clothing. Berikut data pengukuran memakai VRIO model sebagai berikut:

Tabel 3. Data SCA dan VRIO Model Humingbad Clothing

\begin{tabular}{|c|c|c|c|c|c|c|}
\hline No & Types of Resource or Capability & Valuable & Rare & $\begin{array}{l}\text { Costly } \\
\text { to } \\
\text { Imitate }\end{array}$ & $\begin{array}{c}\text { Non } \\
\text { Substitab } \\
\text { le }\end{array}$ & Competitive Consequence \\
\hline 1 & $\begin{array}{l}\text { Menjadi tempat operasional usaha, } \\
\text { display produk dan sebagai inventori }\end{array}$ & Yes & No & Yes & No & Competitive Parity \\
\hline 2 & $\begin{array}{l}\text { Mampu menjadi tempat } \\
\text { operasional, inventori, dan ruang } \\
\text { tamu }\end{array}$ & Yes & No & Yes & No & Competitive Parity \\
\hline 3 & $\begin{array}{l}\text { Bangunan luas dan mampu menjadi } \\
\text { tempat untuk seluruh workshop } \\
\text { konveksi seperti penyimpanan, } \\
\text { penyablonan, ruang tamu, hingga } \\
\text { tempat display produk }\end{array}$ & Yes & No & Yes & No & Competitive Parity \\
\hline 4 & $\begin{array}{l}\text { Memiliki variasi dan jumlah alat } \\
\text { produksi yang bermacam-macam } \\
\text { sehingga dapat memenuhi penawaran } \\
\text { yang ada }\end{array}$ & Yes & Yes & Yes & Yes & Sustained Competitive Advantage \\
\hline 5 & $\begin{array}{l}\text { Karyawan berkompetensi untuk } \\
\text { melakukan pekerjaannya }\end{array}$ & Yes & Yes & Yes & Yes & Sustained Competitive Advantage \\
\hline
\end{tabular}




\begin{tabular}{|c|c|c|c|c|c|c|}
\hline 6 & $\begin{array}{l}\text { Memiliki } 3 \text { karyawan untuk } \\
\text { melakukan proses produksi }\end{array}$ & Yes & Yes & No & No & Temporary Competitive Advantage \\
\hline 7 & $\begin{array}{l}\text { Memiliki berbagai varian jenis bahan } \\
\text { baku sesuai produk yang dipesan }\end{array}$ & Yes & No & Yes & No & Competitive Parity \\
\hline 8 & $\begin{array}{l}\text { Mampu menjaga rantai pasok bahan } \\
\text { baku secara berkelanjutan }\end{array}$ & Yes & Yes & Yes & Yes & Sustained Competitive Advantage \\
\hline 9 & Memiliki modal kas sebesar $50 \mathrm{jt}$ & Yes & No & Yes & No & Competitive Parity \\
\hline 10 & $\begin{array}{l}\text { Memiliki relasi yang baik dengan } \\
\text { supplier dan pelanggan }\end{array}$ & Yes & Yes & Yes & Yes & Sustained Competitive Advantage \\
\hline 11 & $\begin{array}{l}\text { Mampu membangun kekuatan tawar } \\
\text { menawar dengan suplier }\end{array}$ & Yes & Yes & Yes & Yes & Sustained Competitive Advantage \\
\hline 12 & $\begin{array}{l}\text { Membangun hubungan baik dengan } \\
\text { masyarakat sekitar }\end{array}$ & Yes & Yes & No & Yes & Temporary Competitive Advantage \\
\hline 13 & $\begin{array}{l}\text { Mampu menciptakan loyalitas } \\
\text { pelanggan }\end{array}$ & Yes & Yes & Yes & Yes & Sustained Competitive Advantage \\
\hline 14 & $\begin{array}{l}\text { Mampu menjaga citra baik merek di } \\
\text { mata konsumen }\end{array}$ & Yes & Yes & Yes & No & Unused Competitive Advantage \\
\hline 15 & $\begin{array}{l}\text { Pelayanan yang ramah dan cekatan } \\
\text { baik di sosial media maupun offline }\end{array}$ & Yes & No & No & Yes & Competitive Parity \\
\hline 16 & $\begin{array}{l}\text { Mampu menghasilkan inovasi desain } \\
\text { sablon }\end{array}$ & Yes & Yes & Yes & Yes & Sustained Competitive Advantage \\
\hline 17 & $\begin{array}{l}\text { Memiliki konten feeds media sosial } \\
\text { yang menarik dan rapih dan katalog } \\
\text { produk yang dimiliki. }\end{array}$ & Yes & Yes & Yes & Yes & Sustained Competitive Advantage \\
\hline
\end{tabular}

Sumber: Penulis, 2021

Berdasarkan hasil analisis VRIO model diatas, diketahui bahwa Humingbad Clothing memiliki beberapa keunggulan kompetitif yang berkelanjutan atau Sustainable Competitive Advantage atau SCA diantaranya adalah memiliki variasi alat produksi, para karyawan yang kompeten, mampu menjaga rantai pasok bahan baku secara berkelanjutan, memiliki relasi yang baik dengan supplier dan pelanggan, mampu membangun kekuatan tawar menawar dengan supplier, mampu menciptakan loyalitas pelanggan, mampu menghasilkan inovasi desain sablon, dan memiliki konten feeds media sosial yang menarik serta informatif mengenai katalog produk yang dihasilkan. Keunggulan Humingbad clothing itulah yang bisa menguatkan perusahaan untuk bersaing dipasar konveksi.

Selanjutnya dilakukan analisis TOWS untuk mengetahui ancaman, peluang, kelemahan dan kekuatan dari perusahaan Hummingbad pada saat ini. Ancaman sendiri bagi Humingbad adalah bersaing dengan merk besar, karena posisi perusahaan yang masih berkembang, kurangnya inovasi produk menjadi kelemahan tersendiri bagi Humingbad, untuk itu perlu ide-ide baru untuk meningkatkan inovasi perusahaan agar bisa bersaing bersama merk besar. Berdasarakan ancaman yang ada, peluang yang tinggi yaitu promosi digital yang ditingkatkan, selain promosi secara langsung kepada konsumen disekitar tempat tinggal, promosi digital perlu dilakukan untuk menjangkau konsumen yang lebih luas. Pemanfaatan media sosial dengan dikelola dengan menarik menjadi nilai lebih untuk perusahaan dan menjadi salah satu faktor pendorong perusahaan menjangkau konsumen yang lebih luas khususnya sesama pengguna jejaring sosial. Penggunaan periklanan seperti memanfaatkan Instagram Ads bisa meningkatkan jangkauan perusahaan kepada konsumen sehingga pengguna bisa mengetahui dan mengenal perusahaan konveksi Humingbad. Selain itu, perlu pengelolaan konten media sosial yang menarik serta langkah-langkah strategis dalam penggunaan Instagram Ads.

Berdasarkan hasil data yang didapat dari akun media sosial Instagram Humingbad yaitu data jangkauan atau Reach mereka didapat hasil 279 akun yang dijangkau dengan impresi sebanyak 4.190, dilihat dari hasil data dengan promosi yang dilakukan saat ini masih dibilang kurang efektif, sesuai dengan wawancara 
langsung dengan pemilik dari perusahaan Humingbad Clothing yaitu Holis Hidayatulloh, menjelaskan bahwa jangkauan akun tersebut terbilang masih kurang, bahkan dilihat dari jumlah pengikut akun sosial medianya masih jauh dari setengahnya. Untuk itu permasalahan yang dihadapi adalah minimnya promosi digital yang dilakukan sehingga mengakibatkan jangkauan konsumen kurang luas. Hal ini bisa menjadi ancaman dan menghambat perkembangan perusahaan itu sendiri dan jika masalah ini masih belum terselesaikan maka Humingbad akan kalah dengan merk besar.

Maka melihat dari permasalahan atau isu bisnis yang telah ada, usulan program untuk mengatasi kecilnya jangkauan akun media sosialnya sesuai dengan matrik Reach yaitu:

Peningkatan promosi digital melalui Instagram Ads dengan pengelolaan yang optimal. Dengan indikator input, proses, output, outcome, benefit dan impact sebagai berikut:

\section{Input}

Dalam melaksanakan iklan Instagram Ads perlu biaya yang dikeluarkan untuk membayar iklan tergantung paket harga yang akan diambil, semakin tinggi harganya semakin luas jangkauan pengguna yang akan diraih serta periode waktu tayangan iklan tersebut. Pembentukan desain konten seperti mencantumkan merek, pricelist harga, bentuk produk yang dihasilkan serta promo yang dihadirkan. Visual konten menjadi kunci dalam menarik minat konsumen sehingga desain yang informatif harus dimaksimalkan.

2. Proses

Untuk menggunakan Instagram Ads ada beberapa hal yang perlu dilakukan seperti menentukan bentuk iklan, yang direkomendasikan adalah Story Ads melalui Instastory karena pengguna lebih banyak yang terpengaruh dari Instastory sendiri. Selanjutnya menentukan tujuan iklannya yaitu Kesadaran Merk untuk meningkatkan Brand Awareness dan Jangkauan dengan mode traffic untuk melihat data detail pengunjung yang melihat akun Humingbad. Kemuadian menentukan target audiencenya seperti lokasi Ciamis yang utama serta tetangga kota guna meperluas pangsa pasar, umur, hobi dan kegiatan detail lainnya ditentukan dengan target market dari Humingbad yaitu kelompok atau komunitas yang membutuhkan identias pakian. Selanjutnya memilih jenis iklan seperti video atau foto, menentukan konten serta tampilan promosinya. Terakhir adalah penentuan jadwal kapan tayangan iklan ini dilakukan dan pembayaran.

3. Output

Yaitu untuk meningkatkan jangkauan dari akun media sosial Humingbad, meningkatkan jumlah followers yang signifikan tanpa harus membeli followers. Penggunaan fitur user generated content berfungsi untuk membagikan testimoni dari pelanggan.

4. Outcome

Dengan menggunakan Instagram Ads, perusahan mendapatkan promosi melalui Story Ads yang meningkat serta mempengaruhi minat beli konsumen sehingga meningkatkan penjualan perusahaan. Selain itu, Story Ads bisa menjadi undangan atau teaser kepada konsumen. Menggunakan iklan Instagram Ads, perusahan dapat menjangkau pengguna media sosial lebih luas sesuai algoritma Instagram.

5. Benefit

6. Citra perusahaan meningkat sehingga bisa dipandang positif luas oleh pengguna media sosial. Banyak pengguna media sosial terkait yang mengunjungi akun media sosial Instagram Humingbad sehingga meningkatkan tingkat traffic pengunjung perusahaan.

7. Impact

8. Melalui penggunaan iklan Instagram Ads diharapkan perusahaan bisa memenuhi permintaan konsumen dengan pelayan yang optimal. Menginformasikan mengenai profile perusahaan serta mempermudah konsumen melihat katalog produk yang dibuat oleh perusahaan. Selain itu, mempermudah proses transaksi konsumen dikarenakan alur pembelian sudah jelas tertera, konsumen hanya tinggal menjelaskan kebutuhan apa yang diingikan, hal ini proses transkasi konsumen lebih simple. 


\section{KESIMPULAN}

Strategi peningkatan jangkauan atau Reach media sosial Instagram Humingbad yang didasari dengan bagaimana upaya peningkatan jangkauan yang harus dilakukan Humingbad untuk menjangkau konsumen yang lebih luas. Penelitian ini menggunakan beberapa metode analisis yang diantaranya adalah analisis internal perusahaan yang sudah diteliti, terdapat sumber daya yang dimiliki perusahaan seperti media sosial yang terkonsep, modal perusahaan yang memadai serta karyawan yang berkompeten untuk menunjang periklanan dimedia sosial. Selain itu, digunakan metode analisa model VRIO, Humingbad Clothing memiliki keunggulan diantaranya memiliki pengelolaan feeds Instagram yang menarik dan terkonsep sehingga memiliki kompetitif yang berkelanjutan atau Sustainable Competitive Advantage. Selanjutnya, dilakukan analisis menggunakan analisis TOWS menunjukan bahwa terdapat kekuatan dan keunggulan Humingbad yaitu loyalitas pelanggan serta kedekatan Humingbad terhadap suplier dan konsumen. Berdasarkan analisis menggunakan keempat metode yaitu Internal Based Resource, VRIO Model, SCA dan analisis TOWS diusulkan progam dengan penggunaan Instagram Ads sebagai langkah untuk meningkatkan promosi digital perusahaan. Ketika Humingbad Clothing menggunakan Instagram Ads dengan pengelolaan konten yang inovatif dan kreatif serta membuat strategi dengan ketentuan- ketentuan yang berlaku sesuai algoritma Instagram, hal tersebut memberikan dampak positif bagi perusahaan itu sendiri, peningkatan jumlah followers semakin tinggi membuat pengguna media sosial yang dijangkau oleh Humingbad Clothing. Hal tersebut menunjang keberhasilan perusahaan dalam melakukan promosi digital khususnya peningkatan akun media sosial Instagramnya melalui periklanan Instagram Ads dengan media Story Ads.

\section{UCAPAN TERIMAKASIH}

Pada akhir penilitian ini dibuat, penulis menyampaikan ucapan terimakasih kepada pihak yang terlibat dalam pembuatan penlitian ini khususnya dukungan yang diberikan oleh perusahaan Humingbad Clothing untuk memenuhi kebutuhan data perusahaan untuk menunjang penelitian.

\section{REFERENSI}

Aprinta, G. (2016). Pemanfaatan Facebook Ads untuk Meningkatkan Brand Awareness pada Produk Lokal. Nomor 1. Edisi Januari.

Brahmana, Rayenda., K. (2007). Identifying Financial Distress Condition in Indonesia Manufacture Industry. Birmingham Business School, University of Birmingham United Kingdom. Halaman 1-19.

Chaffey, D. (2011). E-commerce \& E-business Management 5th Edition. New Jersey: Prentice Hall.

David, Fred R. (2009). Manajemen Strategis Konsep. Buku 1. Penerbit Salemba Empat. Jakarta.

Faisal, I, A., Rohmiyati, Y. (2019). Analisis Pemanfaatan Media Instagram Sebagai Promosi Perpustakaan Provinsi Jawa Tengah. Jurnal Universitas Diponogoro. Retrieved from https://ejurnal3.undip.ac.id/article

Farris, Paul W., Neil T. Bendle., Philip E. Pfeifer., David J. Reibstein., (2015). “Marketing Metrics: The Definitive Guide to Measuring Marketing Perfomance". Third Edition. New Jersey: Pearson Education.

Hadining, F. Aulia., Iriana, S., \& Kusnadi. (2019). Analisis Kategori Iklan Berbasis

Facebook Ads untuk UKM. Jurnal Teknologi Rekayasa. Vol. 4. No. 1. Hartono,

Jogiyanto. (2009). Sistem Teknologi Informasi Yogyakarta: Andi.

Kaplan, A., \& Haenlein, M., (2010). User of The World, Unite! The Challenges and Opportunities of Social Media, Business Horizons.

Kotler, Philip. (2005). Manajemen Pemasaran. Jilid 1 dan 2. Jakarta : PT Indeks Kelompok Gramedia.

Kotler, Philip., \& K. K. Lane. (2007). Manajemen Pemasaran. Edisi 12. PT Indeks, Jakarta. S, William Pattis., (1993). Karir Bisnis dalam Periklanan, Edisi 1. Dahara Prize. Semarang. 
Sanjaya, Ridwan., \& Tarigan, J., (2009). Creative Digital Marketing. Jakarta: PT Elex Media Komputindo.

Situmorang, J. (2016). Metrik Pemasaran Sebagai Alat Untuk Mengukur Kinerja Pemasaran Perusahaan (Studi Kasus Pada Bisnis Ritel). Jurnal Administrasi Bisnis, 6(2), pp.2161249

Sugiyono. (2007). Metode Penelitian Kuantitatif Kualitatif dan R\&D. Bandung: Alfabeta. 